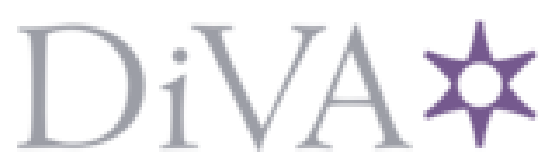

http://www.diva-portal.org

This is the published version of a paper published in California Management Review.

Citation for the original published paper (version of record):

Florén, H., Frishammar, J. (2012)

From Preliminary Ideas to Corroborated Product Definitions: Managing the Front End of New

Product Development.

California Management Review, 54(4): 20-43

http://dx.doi.org/10.1525/cmr.2012.54.4.20

Access to the published version may require subscription.

N.B. When citing this work, cite the original published paper.

Permanent link to this version:

http://urn.kb.se/resolve?urn=urn:nbn:se:hh:diva-19399 


\title{
From Preliminary Ideas to Corroborated Product Definitions: \\ Managing the Front End of New Product DeVelopment
}

\author{
Henrik Florén \\ Johan Frishammar
}

Front-end activities largely influence the outcomes of new product development processes, because it is here that firms create new ideas, give them direction, and set them in motion. We show that the front end can be understood as comprising three core activities: idea/concept development, idea/concept alignment, and ideal concept legitimization, which allow firms to create corroborated product definitions. This article provides important implications for managers interested in front-end management. It devotes specific attention to the differences between incremental and radical front-end development and to the front end in the light of increasingly open innovation processes. (Keywords: Innovation management, Front end, Ideation, New product development, Open innovation, Opportunity recognition)

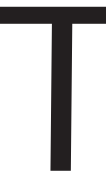

oday, new product development (NPD) is managed systematically in most large companies. Stage-gate processes have been implemented to ensure that resources are allocated so as to provide the company with competitive new products. ${ }^{1}$ Still, many NPD projects and programs fail to meet objectives, and the root causes of these failures can often be traced to the front end. The front end is the stage during which ideas are created and further developed into product concepts and definitions, ending with a "go" or "no go" decision about whether to continue into formal NPD or not. ${ }^{2}$ The quality of the front-end work, which feeds into formal NPD, is therefore critical to NPD performance. ${ }^{3}$

Front-end activities often take place in informal organizational settings, are often ill-defined, and are characterized by ad hoc decision making ${ }^{4}$ and by high degrees of complexity, uncertainty, and equivocality. ${ }^{5}$ The front end is also a crossroads of complex information processing, tacit knowledge, and conflicting organizational pressures. ${ }^{6}$ Many of the challenges following these characteristics are further reinforced when firms engage in radical development efforts ${ }^{7}$ or,

The authors would like to thank the Swedish Governmental Agency for Innovation Systems (Vinnova) for funding this research. Three anonymous CMR reviewers provided valuable feedback on drafts of the article. 
under conditions of open innovation processes, which are marked by active inward and outward technology transfer. ${ }^{8}$

Hence, the front-end stage is a slippery slope, yet critical to end results in NPD. The consequences of mistakes are potentially devastating and have put several highperforming firms into great difficulties. For example, Hasselblad, the famous camera manufacturer, almost went bankrupt due to frontend deficiencies. Because of harsh screening procedures, Hasselblad terminated its own early attempts at a digital camera in the premium segment, a decision that opened it up for competitors such as Nikon and Canon to take big segment shares. Another example is Xerox, which failed to profit from emergent technologies developed at the famous Palo Alto Research Center due to deficient front-end screening procedures. ${ }^{9}$

Henrik Florén is Associate Professor of Industrial Management at the Center for Innovation, Entrepreneurship and Learning Research (CIEL) at Halmstad University, Sweden.

Johan Frishammar is Professor at Entrepreneurship \& Innovation and centre director for Promote (http://promote.se) at Luleå University of Technology, Sweden.

Hence, problems with unclear or incorrect product definitions cause high costs and/or failure at later stages of NPD. ${ }^{10}$ Better guidelines are therefore needed to support the management of the front end so that better choices can be made and unnecessary costs avoided. ${ }^{11}$ Specifically, many companies today do not primarily suffer from a lack of good ideas for new products. Rather, their key challenge lie in the shaping process that allows ideas to move forward; to be processed and refined in a way so that management can "pick the winners" that eventually become valid and reliable input into formal NPD. Three things are needed to address this challenge. First, firms need a better understanding of what is the outcome of the front end. Second, they need a clear understanding of which activities have to be performed in the front end. Third, knowledge about potential countermeasures to avoid pitfalls in these activities is needed.

To this background, this article develops a comprehensive framework in which the outcome of the front end is depicted, and the key activities that firms conduct are identified and explored. Although studies of the front end have increased in recent years, they still provide an incomplete guide to effective front-end management. Four reasons for this are conceivable. First, the literature has not reached consensus about the outcome and key activities of the front end. Concerning the front-end outcome, authors use different proxies for success focusing on the frontend process rather than on the outcomes of that process. ${ }^{12}$ Second, there are indeed articles that review the literature and advise practitioners. ${ }^{13}$ However, many of these list a variety of success factors but fail to provide clarity with a parsimonious yet comprehensive account of the front end. Third, common pitfalls and appropriate managerial countermeasures seem contingent on whether a firm is involved with incremental or radical development. Some prior research has addressed the differences between radical and incremental innovation, but the differences between the two is still insufficiently understood. ${ }^{14}$ Fourth, prior front-end literature has not fully accounted for recent developments in the open innovation literature, especially regarding the outbound dimension of open innovation. ${ }^{15}$ This article targets these four research gaps.

The front end can be understood as three key activities: idea and concept development, idea and concept alignment, and idea and concept legitimization. 
When conducted proficiently, these key activities allow firms to create corroborated product definitions. Such product definitions, which represent the main outcome of the front end, have been exposed to various forms of tests, analyses, and criticism and have withstood them. Our analysis shows that pitfalls in the key activities are rather generic, whereas appropriate managerial countermeasures are contingent on whether firms are involved with incremental or radical front-end development.

\section{Towards an Integrative Framework for the Front End of NPD}

The theoretical interest in the front end has continued to rise in recent years because research studies in multiple fields have underscored the importance of the activities that constitute the front end. For example, scholars adopting a social network perspective show that infrequent social relationships with people outside a firm's boundaries can provide unique knowledge to support the creation and development of new creative ideas and concepts. ${ }^{16}$ Furthermore, front-end activities allow firms to both recognize, sense, and shape opportunities, as pointed out by research in the capability-based literature. ${ }^{17}$ To identify and shape ideas and opportunities, firms must scan, search, and explore across technologies and markets, ${ }^{18}$ which constitute the key activities of the front end. In addition, front-end issues have been addressed in the literature on opportunity recognition $^{19}$ and concept development. ${ }^{20}$ The front end has also been studied in NPD research, which underscores that front-end activities are key determinants of high performance. ${ }^{21}$ We draw on these prior literatures and insights in extracting the key elements of our framework (see Figure 1). ${ }^{22}$

Fundamental to developing a corroborated product definition is (1) a wellfunctioning idea and concept $(I / C)^{23}$ development process, which implies a set of transformations of input elements into output elements. The key input element is an "idea" representing a recognized opportunity. ${ }^{24}$ The idea is subsequently transformed into a product concept, and later a product definition. I/C development,

FIGURE I. A Comprehensive Framework of the Front End of New Product Development

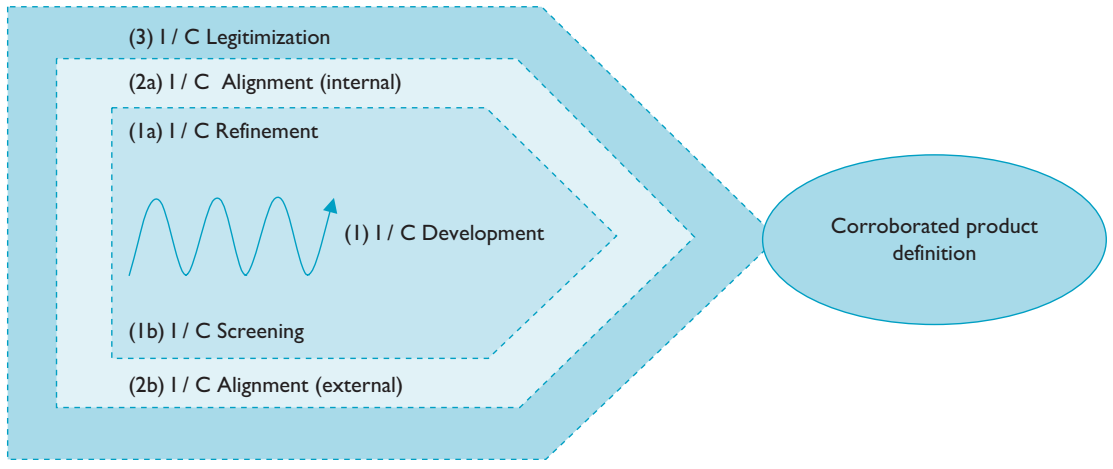


in turn, consist of two interrelated sub-activities: (la) I/C refinement and (lb) I/C screening.

I/C development constitutes the core of the framework but must be complemented by (2) I/C alignment and (3) I/C legitimization. I/C alignment addresses how firms strategically align an idea with its (2a) internal and (2b) external environment. I/C legitimization acknowledges the socio-political dimension and the need for creating organizational commitment in the front end.

As shown in Figure 1, several preconditions must be fulfilled for a corroborated product definition to emerge. First, firms need high-quality I/C development, characterized by adequate I/C refinement and I/C screening that allow them to develop an idea into a corroborated product definition. As implied by the sine curve, these two activities are interrelated and should not be performed in isolation. Rather, during the front end, development personnel need to iterate between idea and concept refinement and screening. In the front end, screening is not exclusive to the gate reviews. While most firms employ formal screening activities, screening also needs to be done more informally, in a continuous manner, and integrated with refinement activities.

Second, companies need the ability to align new ideas with internal preconditions such as the product portfolio and product strategy, and with the external environment as constituted by competitive product offerings, technology, and market development. Finally, a last precondition is that an emerging idea/concept must be made legitimate and perceived as relevant by key stakeholders. If this fails to occur, I/C development may stall or be terminated despite a high-quality idea/ concept or, alternatively, an idea/concept may develop despite evident weaknesses. Or, as is all too common, mediocre ideas/concepts survive the front end, resulting in "me-too products." 25

Figure 1 provides important implications for how the front end should be understood and managed. The absence of distinct phases indicates that frontend projects do not necessarily lend themselves to high degrees of formalization. ${ }^{26}$ Instead, firms need to manage the front end in a way that takes into account its idiosyncratic character, especially in radical development.

The framework also denotes how firms should prioritize in building frontend proficiency and achieving desirable outcomes. The most fundamental element of the front end is I/C development. If a company does not have a well-functioning $\mathrm{I} / \mathrm{C}$ refinement or screening, it does not make sense to spend resources on developing systems for I/C alignment or legitimization. Furthermore, if a company has an adequate I/C development process, it should prioritize to build a system for I/C alignment before allocating resources on securing that the system of legitimization is not hampering $\mathrm{I} / \mathrm{C}$ development.

\section{Front-End Outcomes}

Prior research tends to focus on the front-end process but largely fails to define its outcome. ${ }^{27}$ Rather than employing process measures, we argue that the outcome of the front-end stage is a corroborated product definition, for the following reasons. Core to the product definition is a product concept. The product 
concept is typically visualized in the form of pictures, drawings, three-dimensional models, or mock-ups. ${ }^{28}$ The product concept represents a description of a new product idea, plus its primary features and customer benefits. ${ }^{29}$ Adding to the product concept, the product definition includes information about target markets, customer needs, and product specifications as well as product positioning and product requirements. ${ }^{30} \mathrm{~A}$ well-defined product definition provides a clearer understanding of several important issues, including development time, costs, technical expertise, market potential, risk, and organizational fit. ${ }^{31}$

However, a product definition may still be flawed. Drawing on Popper's idea that scientific laws are falsifiable rather than verifiable, ${ }^{32}$ product definitions cannot be verified to the extent that they become "completely valid"; they can only be said to be presently unflawed. A corroborated product definition implies that it has been subjected to critical tests and has withstood them. It is furthermore sufficiently clear, stable, and unambiguous, and has passed the tests of business and feasibility analysis. Consequently, a corroborated product definition is widely accepted among the involved key actors and stakeholders, e.g., the development team and the review committee.

\section{Idea and Concept Development}

The front end starts with an opportunity being recognized, and this is a process rather than a single event. Typically, the recognizer of an opportunity (for example, a scientist) may have a rough idea of a potential application but a limited understanding of the market. ${ }^{33}$ In order for an idea to be wider recognized by the firm, other actors need to be involved. ${ }^{34}$ Thus, the opportunity recognition cycle starts I/C development and is at the very beginning of the front end.

I/C development constitutes two activities that act as opposite forces. I/C refinement is a propelling force that pushes ideas forward to be continuously refined into a product concept, and later into a product definition that can be evaluated and assessed. I/C screening constitutes a control on the development of product ideas/concepts by means of assessment and evaluation.

\section{Idea and Concept Refinement}

I/C refinement gives I/C development its key technical contents, energy, and direction and should thus be characterized by creativity and experimentation. During this activity, the development team takes actions to refine a preliminary idea into a product concept, which will later be refined into a product definition. While engineering work clearly is critical to this activity, the features of this work are often qualitative, informal, and approximate rather than quantitative, formal, and precise. $^{35}$

The front-end stage is thus conceptualized as starting with the surfacing of an idea by means of opportunity recognition. ${ }^{36}$ A new product idea is a mental picture of a possible and feasible solution to a problem. ${ }^{37}$ The quality of the idea is critical and can "make or break the project." ${ }^{38}$

The main reason for I/C refinement being important is that the vast majority of ideas will eventually prove unsuccessful. ${ }^{39}$ Thus, one important part of I/C 
refinement is calculating risks ${ }^{40}$ and reducing uncertainty. From this follows that the members of the development team need to be able to seek relevant information and evaluate it quickly, e.g., information about changes in technology, markets, internal organizational developments, and competitors that can be used in reducing uncertainties. ${ }^{41}$

However, the mere collection of reliable information to reduce uncertainties is an insufficient precondition for efficient I/C refinement. Past data, experiences, and intuition are also essential elements in the refinement process. ${ }^{42}$ Firms therefore need to develop skills in probing and learning, ${ }^{43}$ and they must be prepared to make intermittent changes to the idea and concept under development. ${ }^{44}$ Consequently, firms need develop their experimental abilities in addition to pure analytical ones as I/C refinement is a matter of trial and error with feedback loops feeding into the refinement process.

Proficiency in I/C refinement allows for a more productive pipeline that permits firms to move quickly from new ideas to concepts that can be further refined, rather than spending time on "apparently failing ideas." ${ }^{45}$ Accordingly, poorly executed I/C refinement often results in costly problems at later stages of NPD. ${ }^{46}$ For example, Daimler experienced severe refinement problems when first launching the Mercedes A-class car that overturned when pushed to the limits. The product had to undergo significant reengineering before it was finally launched into the market. ${ }^{47}$ To mitigate such problems from occurring, firms may rely on "Design Structure Matrices" ${ }^{48}$ to better depict the key dynamics of the front end.

More specifically, the refinement of product ideas and concepts is propelled first by the internal cooperation between functions and departments. ${ }^{49}$ The importance of firm-internal cooperation cannot be overstated because it reduces the number of bad ideas and increases the number of productive ideas in innovation. ${ }^{50}$ Although R\&D and marketing integration appears most important during the front end, ${ }^{51}$ engineering, manufacturing, and process design also need to be involved. ${ }^{52}$ At Philips Electronics, this has been implemented by means of the product-technology roadmap process in which competences from many different organizational functions are pooled to improve I/C refinement. ${ }^{53}$

However, research into team composition/structure indicates that the organization of development teams affects the quality of ideas being developed. Firms should ensure that I/C refinement is conducted in a mode where team members combine individual work with the group work mode, because such a "hybrid" structure not only generates more ideas, it also generates ideas of better average quality. ${ }^{54}$

In addition to internal collaboration, the refinement of product ideas and concepts is propelled by cooperation with external actors, ${ }^{55}$ the most obvious being key customers. Clearly, customer needs must be well understood before actual development starts, ${ }^{56}$ and early assessment of customer needs contributes strongly to product success. ${ }^{57}$ In addition, customer involvement can allow new and diverse viewpoints beyond those of the development team. ${ }^{58}$ To this background, even the traditional or so-called "closed" models of the innovation process $^{59}$ were surprisingly open in the front end, at least concerning inbound activities such as customer or supplier involvement. 
One example underscoring the value of thoroughly understanding customer needs during I/C refinement is Sony's development of the Vaio W computer. The computer was developed after front-end market research showed that Japanese consumers bought laptops mainly because they took up limited space. The outcome of the development process was a small computer that sold more in a single day than the expectations for the first month of sales. ${ }^{60}$ Another example can be found at the ITT Corporation that has implemented Value Based Product Development as an approach to ensure high quality voice-of-customer input into the front end of NPD. ${ }^{61}$

However, external collaboration is not limited to customers. One key task during the front end is to reduce technological uncertainty, which can be achieved by partnering with competent suppliers. ${ }^{62}$ Supplier collaboration can also reduce development costs and time-to-market, and it can enable higher product quality. ${ }^{63}$ Cooperation with external actors such as governmental agencies and higher educational institutions-or even competitors-also seems important to idea refinement proficiency. ${ }^{64}$ In sum, active technology transfer appears a critical precondition in the front end. ${ }^{65}$ This appears especially important in domains where firms lack critical prior knowledge, thus allowing partners to fill this gap. ${ }^{66}$ For example, Nokia dropped its own heavily criticized Symbian platform for smart phones in favor of Microsoft's Windows Mobile platform to potentially increase performance of future products. ${ }^{67}$

\section{Idea and Concept Screening}

While I/C refinement primarily concerns propelling I/C development, screening of ideas and concepts concerns the issue of ensuring relevance in terms of, for example, the correct product attributes and customer benefits. In essence, I/C screening involves the continuous activities undertaken by a firm that aim to determine whether an idea/concept, at its specific stage of refinement, should be further developed or not. Ideas and concepts are filtered through a process to ensure effective allocation of resources ${ }^{68}$ in order to weed out the "bad ideas" and make sure that the "good ideas" are not terminated. High-performing firms tend to deal with screening systematically. For example, 3M launched its "Pacing Program" to identify and sort out, among the thousands of projects in progress at any time within $3 \mathrm{M}$, the hundred or so which could "change the basis of competition." ${ }^{69}$

However, screening is often performed poorly, because many firms use screening only to make rough decisions to get rid of obvious "loser projects." 70 This observation is further supported by recent research, which reveals that most companies have policies to limit "false positives" in early development projects but are poorly prepared to address "false negatives."71

Early in the front end, screening typically isn't very sophisticated. ${ }^{72}$ The screening process should make use of metrics that allows for a contextualized evaluation of ideas and concepts that fits with the situation of the firm. Typically, these measures center on assuring that ideas and concepts satisfy market needs, are technologically feasible, add value to the product portfolio of the firm, and fit with the business strategy. ${ }^{73}$ In terms of which criteria firms should use, 
recent research suggests a need to develop a holistic evaluation system including both qualitative and quantitative criteria, as well as methods that measure and aggregate multiple criteria. ${ }^{74}$

Due to involvement and commitment, teams may lose their ability to critically screen and assess their own ideas, so a hybrid structure combining individual work and teamwork is beneficial in I/C screening. ${ }^{75}$ However, screening is also performed by a group of executives acting as gatekeepers. ${ }^{76}$ An executive review committee is an important filtering function during the front end to ensure that screening is not blinded by path-dependent learning efforts of the team. ${ }^{77}$ Screening committees should be composed of individuals who can openly discuss ideas and concepts, because an open climate favoring risk taking, trust, and interaction positively influences front-end activities. ${ }^{78}$

I/C screening can be conducted within formal as well as informal settings, by both internal and external actors. For example, innovation intermediaries can be helpful in performing screening tasks. ${ }^{79}$ Terminating inferior product ideas and concepts early can result in large cost savings. ${ }^{80}$ It might seem obvious that the faster a firm's product ideas and concepts can be evaluated-and, if flawed, terminated-the better off the firm will be, because it then spends energy only on viable concepts. However, intensive and dogmatic screening can kill good ideas too early, thereby preventing companies from gaining future revenues from unrealized opportunities.

For example, General Electric failed to capture value from technology due to an inappropriate set of selection criteria. ${ }^{81}$ Other firms, such as $3 \mathrm{M}$, deal with the risk of too harsh screening by building a culture that accepts "well-intentioned failure." 82

I/C screening takes place in two different but related domains. ${ }^{83}$ The purpose of business analysis is to screen a new product idea/concept in terms of its viability as a business proposition. Put simply, business analysis ensures that a development effort is grounded in a potential for financial profitability. Feasibility analysis determines whether a firm can support a development project with sufficient resources. ${ }^{84}$

Another key issue in I/C screening is uncertainty reduction through technology assessment-a crucial activity prior to formally investing in a project. ${ }^{85}$ The key question concerns the technical viability of the concept. Technology assessment means answering the questions of whether the product can be developed, what technical solutions will be required, and at what cost. Finally, firms need to ask whether the product can be manufactured. ${ }^{86}$

\section{Idea and Concept Alignment}

The third key activity central to front-end outcomes is I/C alignment. On the one hand, alignment concerns assuring fit between the emerging idea/concept and the firm's strategy and internal operations. On the other hand, it seeks to achieve fit between the idea/concept and the firm's external environment. In short, ideas and concepts must be developed to fit with both internal and external requirements, at least if internal development is the preferred commercialization mode. ${ }^{87}$ 
Concerning the internal dimension of I/C alignment, a product concept that displays good alignment with a firm's overall strategy has a much better chance of being executed. ${ }^{8}$ Hence, high-performing firms link product-specific decisions with business and product strategy in the front end. ${ }^{89}$ A recent example is Apple, whose key design elements and component technologies reappear throughout the firm's different product lines.

A failure to align I/C development with the overall strategies of the firm is a common mistake. For example, successful projects capitalize in some way on the core competences of their firms ${ }^{90}$ whereas unsuccessful projects do not. It is thus important to achieve fit between the product idea and the operating capabilities of the firm. ${ }^{91}$ Other frequent deficiencies are that decision making is based on project-specific criteria rather than on requirements of strategic fit, and that the RED department funds projects based on superior technology rather than on what is actually required by a firm's products. ${ }^{92}$ An important part of internal I/C alignment is thus product portfolio planning, implying that a firm has to develop product definitions that will over time provide them with an optimal mix of product attributes to customers. ${ }^{93}$ Firms should therefore acknowledge that current product definitions might have important implications for future product development if the firm plans to release future products with the current product definition as a platform.

A critical aspect of I/C alignment is thus to ensure that ideas and concepts add value to the firm's product portfolio and that the product strategy is sustained. For example, Black $\delta$ Decker developed a new common universal motor that replaced the hundreds of different motors previously manufactured for different production lines. This change enabled the firm to market a lighter and more profitable drill at a much lower price than its main competitors. This gave Black $\delta$ Decker a strong competitive position that made it a dominant actor in the market despite the entrance of offshore manufacturers. ${ }^{94}$

Firms should also assure that the project portfolio fits with resource capacities of the firm so that maximum value from investments is gained. ${ }^{95}$ This implies that front-end efforts should contribute to the development of existing products in order to exploit their position in the product lifecycle, in addition to developing new products that eventually can replace products in the decline stage. Thus, proficient internal alignment of ideas and concepts allow firms to sustain an adequate flow of new product introductions. ${ }^{96}$

Typically, ideas and concepts possess sufficient internal alignment. This will, however, not always be the case. To capitalize also on the circumstances where the lack of internal alignment prohibits further internal development, firms could consider building "desorptive capacity." Desorptive capacity describes a firm's capability of external knowledge exploitation ${ }^{97}$ and refers to outward knowledge transfer. ${ }^{98}$ Because of imperfections in the markets for ideas, ${ }^{99}$ "desorpting" ideas and concepts may be a major challenge for firms. Still, studies of Lucent and other firms show that investment in such capabilities may very well be a worthwhile endeavor. ${ }^{100}$

The external dimension of I/C alignment concerns the need to align I/C development with factors outside firm boundaries, such as competitive product offerings and technological development. For example, both prospective and 
current product offerings of competitors need attention. Research has shown that successful teams generally make such an analysis, whereas information on competing technologies and products was often unavailable or ignored in less successful teams. ${ }^{101}$

Indeed, failure to provide sufficient external alignment to I/C development in the front end can be both dangerous and disastrous. Motorola's development of the Iridium satellite telephone provides an illustrative example. Besides overestimating the size of the market for satellite phones, Motorola underestimated the speed at which conventional cellular coverage would spread around the world, leading the firm to develop a product that provided small revenues at great costs. Xerox, on the other hand, recognized the threat of digital technology to its lens copier product line and developed a new generation of copiers and printers that were based on digital technology.

When lack of external alignment is the major problem, firms can engage in building absorptive capacity, thus improving the abilities to recognize, assimilate, and apply external knowledge. ${ }^{102}$ Absorptive capacity thus focuses on improving knowledge acquisition. For example, Cisco has significantly improved its I/C development activities relative to competitors by building absorptive capacity. ${ }^{103}$ Another way of mitigating the problem with insufficient external I/C alignment is to partner with firms possessing adequate absorptive capacity. ${ }^{104}$

Both internal and external I/C alignment appear crucial to front-end outcomes. When alignment is low or missing, a firm may face three types of risks (see Figure 2).

Risk Type A results from a failure to align I/C development with the external environment, although sufficient internal alignment has been obtained. Xerox, for example, was established by employing a new and efficient business model to commercialize a technology rejected by other companies at that time. Later on, however, that same business model made Xerox fail to commercialize several of its spin-offs, because the market potential for these was assessed from the perspective of Xerox's established (and previously successful) business model. This example underscores that an overemphasis on internal alignment while ignoring external alignment risks undermining a firm's possibility to capture value

FIGURE 2. Three Types of Risks in I/C Alignment

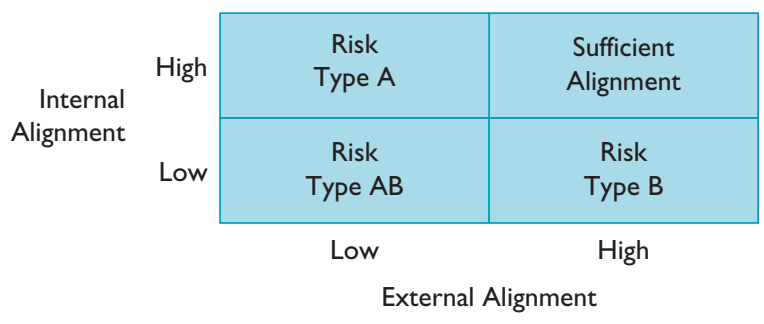


from early-stage development activities. ${ }^{105}$ Another example in a similar vein is when firms allocate resources solely to projects that target already powerful customers, ${ }^{106}$ thus undermining their possibility to reach new customers with novel concepts.

Risk Type B surfaces when a firm fails to achieve sufficient internal I/C alignment. Here, the firm fails to exploit the value creation potential that is encapsulated in the core competencies of the firm and in existing products. This risk applies specifically to firms pushing for radical innovation, because such firms risk overemphasizing external alignment of I/C development at the expense of internal alignment. This risk was pinpointed by James Kilts, former Chairman and CEO of Gillette, when stating that one of the weaknesses of Gillette was the nurturing of radical innovation: "New products have traditionally been a driver to success for Gillette; in 2001, 40 percent of our sales came from products that weren't around five years ago. But when I joined Gillette a few years ago, I found that there was a lack of incremental innovation across all parts of the company." 107

Risk Type $A B$, combining the above deficiencies, is the most severe situation for firms pursuing internal development, but it poses an opportunity in addition. Clearly, the absence of both internal and external alignment makes further internal development very difficult. However, even though a new idea or concept is not aligned with a company's internal and external context, it may still be of value outside the firm if it fits the business model and/or core competences of some other firm. ${ }^{108}$ If dealt with wisely, this situation may thus allow idea and concept commercialization that can provide the firm with extra revenues.

\section{Idea and Concept Legitimization}

The third key activity affecting the outcome of the front end is I/C legitimization. ${ }^{109}$ The reason for its importance is the need to protect I/C development from being foiled by socio-political factors and issues. ${ }^{110}$ For example, ideas and product concepts often need the help of people other than the inventor in order to develop, concretize, and subsequently be accepted into the "formal" NPD process. ${ }^{11}$ In a similar vein, executive "pet projects" sometimes receive special treatment and allowances to bypass predefined gates. ${ }^{112}$

Thus, the socio-political context is important and needs managerial attention. This is underscored by the fact that large companies "are good at coming up with sound ideas" but "are often poor at carrying them out because of a morass of analysis, approvals and politics." ${ }^{113}$ In addition, Moss Kanter concluded that managers in the early stages of entrepreneurial projects need political information as much as they need technical data. "Without political savvy," Moss Kanter writes, "no one can get a project beyond the proposal stage." ${ }^{114}$

Two key problems follow if a firm fails to address this aspect. The first is that good ideas run the risk of being ignored or rejected because of a lack of legitimization. ${ }^{115}$ The result is lost opportunities for the firm. This is what happened to Hasselblad, where early development of a digital camera was abandoned due to a failure of top management to build commitment and legitimize the project. The 
second problem is that "bad ideas" may be pushed too far in their development because they are supported by powerful individuals within the organization, ${ }^{116}$ with increased costs and a crowded development pipeline as consequences. ${ }^{117}$

A number of actions to deal with the first problem of I/C legitimatization can be identified. Critical is ensuring senior management support. Although front-end activities are typically carried out individually or in small teams, support from senior management is critical to success for multiple reasons. First, it is crucial to overcome resistance to change and thus go beyond initial resourcing and public support. ${ }^{118}$ Second, new product ideas have a much greater probability of being developed if executive champions become personally involved in proposed projects. ${ }^{119}$ Third, senior management support has been found to lead to increased levels of innovation. ${ }^{120}$ Finally, senior management provides resources and helps clarify project objectives. ${ }^{121}$

The importance of I/C legitimization also depends on how I/C development is conducted. If idea development is mainly an individual achievement, management should expect legitimization activities to be more important, as the need for action to create organizational commitment to the idea will be greater. Similarly, I/C legitimization is also contingent on the level of cross-functional integration, which is critical to "keeping an idea alive and active." ${ }^{122}$ Basically, this means that an emerging idea or concept has to be exposed to the review and criticism of knowledgeable individuals from affected functions and departments. If this is not the case, the likelihood of negative effects of socio-political activities is higher.

However, legitimacy can be achieved by other means than teams and cross-functional collaboration. Innovative ideas benefit from leadership by committed enthusiasts. ${ }^{123}$ Such persons are referred to as product champions or idea visionaries. ${ }^{124}$ They have power or authority and can promote the idea/concept to stakeholders to seek and establish commitment. In addition, an idea visionary or product champion is highly committed to the project and brings passion to the table, which allows ideas and preliminary product concepts to persevere in the face of frustration and ambiguity. ${ }^{125}$

The issue of I/C legitimization is also acknowledged in writings on heavyweight project managers, i.e., managers with substantial prior expertise and formal as well as informal influence on development activities. A heavyweight project manager has a great impact on the creation of product definitions, increases team effort, facilitates strategic alignment, creates a greater sense of shared team mission, and enacts clearer project objectives. ${ }^{126}$ A project manager is also often involved with lobbying for support and resources, and coordinates technical as well as design issues. ${ }^{127}$

However, firms also face the challenge of ensuring that bad ideas ("false positives") are not further developed. While committed enthusiasts and heavyweight project managers have been found to secure resources and protect ideas and projects from termination, situations may arise where such persons also support ideas and projects with little or no potential. ${ }^{128}$ This aspect of I/C legitimization can be traced to the fact that "people become attached to ideas over time 
through a social-political process of pushing and riding their ideas into good currency." ${ }^{129}$ If not wisely managed, these social-political processes may lead firms to devote scarce resources to developing inferior ideas and concepts.

\section{Are Radical Front-End Developments Different From Incremental Ones?}

A question not discussed so far is whether radical front-end development can be managed much in the same way as incremental development, or whether radical ideas and concepts force the key activities of Figure 1 to play out differently?

In radical front-end development, the desired outcome is new both to the firm and to the market. ${ }^{130}$ Radical product ideas and concepts therefore pose considerable challenges to teams in the front end. ${ }^{131}$ Such development calls for more iterative and complex problem solving, and market size and price sensitivity are typically more difficult to estimate. ${ }^{132}$ Exploratory or "formative" product definitions are often undertaken prior to a more stable one, which makes the process of developing corroborated product definitions more time-consuming. ${ }^{133}$ Thus, the front end of radical innovation "seems to be an inherently messy process." ${ }^{134}$

Radical innovation also often involves extreme degrees of technological uncertainty, which makes the linking of technological capabilities to market needs more complex. ${ }^{135}$ In managing uncertainty, firms need to consider the issue of timing (an important element in the commercialization phase of NPD) when deciding what levels of uncertainty are acceptable. Specifically, if being early to market is providing the firm with a competitive advantage, firms would typically allow some residual uncertainties in the radical product definition in order not to loose momentum in the development process.

Also, I/C refinement works by a different logic in radical development. ${ }^{136}$ Interpretative knowledge is needed to a larger extent, as is creativity. ${ }^{137}$ Radical front-end development tends to be defined less explicitly. ${ }^{138}$ Furthermore, individual rather than organizational initiative is needed. ${ }^{139}$ In addition, the issue of concept shifting is more apparent in radical development, and participants do not necessarily employ a formal, highly structured front-end process. ${ }^{140}$ Less emphasis is paid to analysis and much more on probing and learning from prior experiences. ${ }^{141}$

The front-end for radical development is not necessarily customer-driven (although sensitivity to customer needs still appears critical). Often, new concepts are not customer-generated and cannot be amenable to up-front market research. Instead, attention is focused on explicating the technical differential advantage that a new concept will offer over existing products and technologies. ${ }^{142}$ Thus, for very novel concepts, most potential users do not have the real-world experience needed to provide accurate data and propose solutions. However, firms may rely on lead users whose present strong needs often become general in the marketplace in the future. Lead users can often serve as a need-forecasting laboratory if used wisely. ${ }^{143}$

Concerning I/C screening, the screening logic is different when entering highly innovative fields, because firms often lack prior critical experience. In the case of incremental development, firms can utilize prior experiences when developing 
similar products when, for example, conducting feasibility analysis. Screening procedures in radical development cannot be based on such experiences. Under such circumstances, the ability to probe and learn becomes more important, and investment in strong collective learning processes may pay off better. ${ }^{144}$ In radical development, there are also significant challenges with respect to validation of key assumptions, ${ }^{145}$ i.e., to proficiently perform the activities of business analysis, feasibility analysis, and technology assessment. Highly formalized screening procedures are also more hazardous when pursuing strategic opportunities in the context of radical development. ${ }^{146}$

When it comes to internal I/C alignment, new radical concepts tend to create needs to change or rework many things in the company-for example, capabilities, business models, and customer networks. ${ }^{147}$ Such concepts and development initiatives may be competence destroying. ${ }^{148}$ Developing radical new products might create unique challenges because prior competences and experiences may be inadequate. ${ }^{149}$ Concerning external I/C alignment, network participation and access to a partner's knowledge can allow firms to overcome the lack of prior knowledge accumulation. ${ }^{150}$

Finally, in I/C legitimization, prior literature points to the critical importance of a product champion or visionary, because in the front end for radical development "it is the visionary who first sees how all the pieces fit together into a particular application for the technology."152

\section{Discussion and Managerial Implications}

The path from the surfacing of new product ideas along the way to corroborated product definitions presents numerous obstacles and managerial challenges that must be addressed if a firm is to become successful in front-end activities. The article contributes with a framework and advice that can guide managerial decision making and support managers in dealing with the front end in both incremental and radical development. The findings not only apply to general managers or project managers, but also extend to development engineers and other participants involved with the early stages of NPD.

Overall, our article identifies three key activities critical to the front end: I/C development (split into I/C refinement and I/C screening); I/C alignment; and I/C legitimization. These three activities explain how corroborated product definitions come about. Table 1 shows the key front-end activities, the common pitfalls in performing these activities, and the key managerial countermeasures appropriate to address these pitfalls. In doing so, the Table also explicates the key differences between incremental and radical front-end development.

The I/C refinement component of I/C development is critical to any frontend process, be it incremental or radical. Although development work is often qualitative, informal, and approximate in nature, I/C refinement provides the key technical contents, energy, and direction to I/C development. ${ }^{152}$ Common pitfalls in I/C refinement are surprisingly similar between incremental and radical development, although insufficient uncertainty reduction and excess formalization 


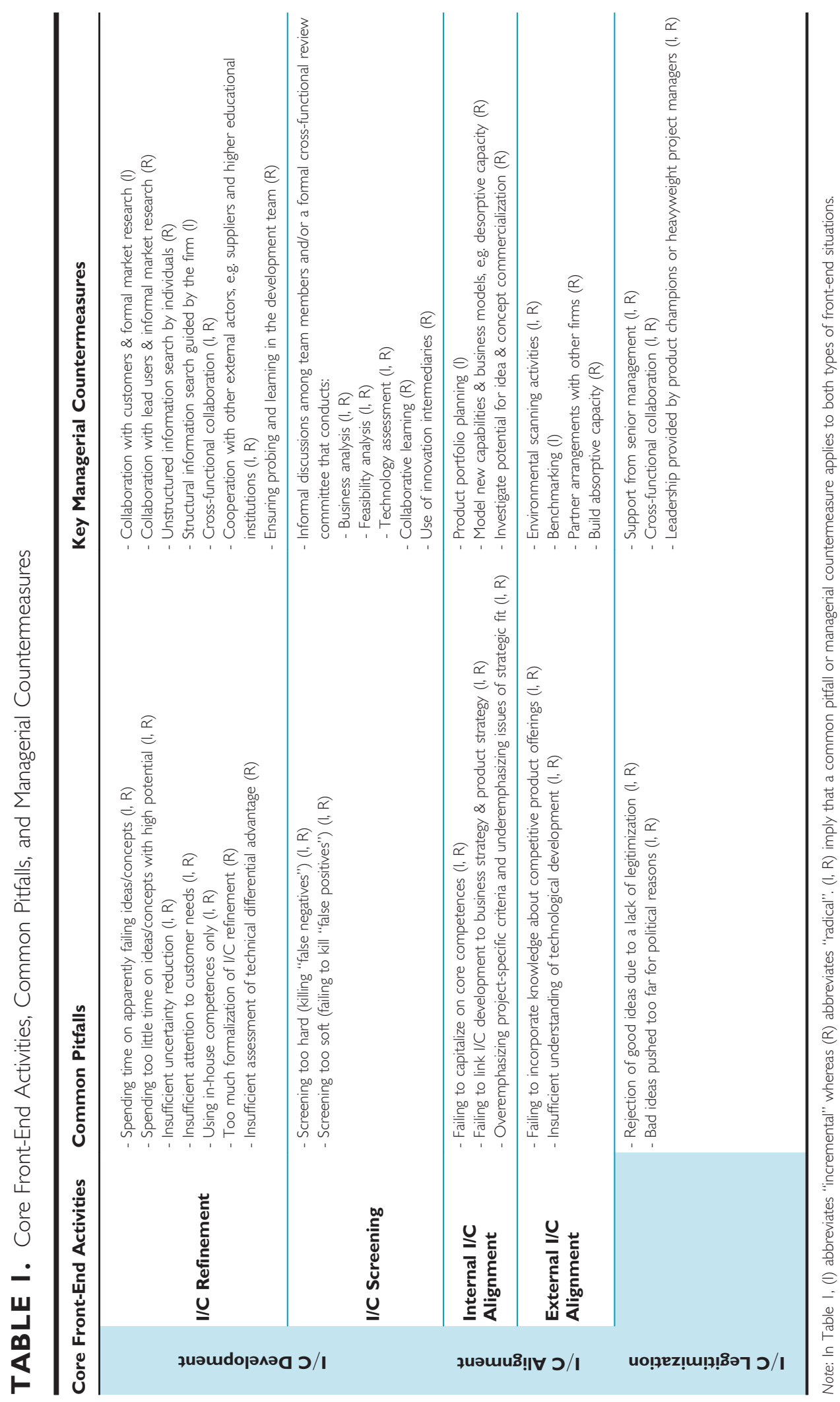


constitute more significant problems in radical development. ${ }^{153}$ In addition, insufficient assessment of technical differential advantage seems to apply to radical development but not to incremental development. ${ }^{154}$

However, even if the pitfalls are similar, appropriate managerial countermeasures diverge. In incremental development, formal market research and collaboration with customers help firms clarify market needs prior to formal development, ${ }^{155}$ and collaboration with suppliers can help shorten the time-tomarket period and increase product quality. ${ }^{156}$ In radical development, firms instead need to trust informal market research and collaborate with lead-users. ${ }^{157}$

Furthermore, for incremental new concepts, structured problems or opportunities can be laid out at the firm level and then be directed to individuals for information gathering. For radical concepts, it seems to work in the opposite direction. That is, action is much more likely to be at the discretion of individuals acting by themselves. ${ }^{158}$ Thus, informal organization appears much more critical in the case of radical development, as is probing and learning. Finally, proficient collaboration between the internal functions and departments involved in the front end is important to both incremental and radical development ${ }^{159}$ and extends not only to R\&D and marketing, but also to manufacturing and process design. ${ }^{160}$ Managers must also sustain collaboration with external actors, such as customers and suppliers. ${ }^{161}$

Companies also need to manage the I/C screening component of I/C development, in both incremental and radical front-end development. Although the screening activities are typically more time-consuming and conducted later in radical development, ${ }^{162}$ the pitfalls of screening too hard or too soft apply to both types of development situations. However, screening activities during radical development need to be more flexible, and teams should be prepared to engage in concept shifting to a greater extent. ${ }^{163}$

Both informal and formal countermeasures are at management's disposal. First, managers can encourage screening conducted by a development team, ${ }^{164}$ as well as utilizing a cross-functional executive review committee acting as gatekeepers. ${ }^{165}$ In both cases, managers need to ensure that a new idea/concept is screened in terms of its viability as a business proposition, as well as on the feasibility dimension. ${ }^{166}$ Moreover, managers should encourage screening of the technical viability of the emergent idea/concept to assess what technical solutions will be required and at what cost. ${ }^{167}$ The screening measures apply to incremental and radical development alike. However, in radical development, firms may complement their screening efforts by engaging in collaborative learning processes. ${ }^{168}$ In addition, in radical development, innovation intermediaries may contribute competence in evaluation and screening, which may be lacking in-house. ${ }^{169}$

Concerning I/C alignment, managers should work deliberately to fit both incremental and radical ideas and concepts with internal as well as external circumstances. For internal I/C alignment, common pitfalls include a failure to capitalize on the core competences of the firm, a failure to consider the business and product strategy when developing new ideas and concepts, and an emphasis on project-specific interests over those of strategic fit. ${ }^{170}$ 
While these problems frequently apply to incremental development, they are perhaps even more common in radical development, which is often competencedestroying by nature. ${ }^{171}$ Thus, the synergy of incremental new ideas and concepts with the firm's existing resources should allow the firm to execute various activities without significant reinterpretation of prior critical knowledge, which will not be the case in radical development. ${ }^{172}$

In the case of incremental innovation, managers should encourage and sustain proficient product portfolio planning, which represents a way to ensure that new product definitions offer the correct product attributes to customers. ${ }^{15}$ In radical development, it may be appropriate to model new capabilities and business models to profit from technology. ${ }^{173}$ A significant example would be investing in desorptive capacity, i.e., a firm's capability of external knowledge exploitation, which could allow firms to profit from ideas and concepts suffering from misalignment. ${ }^{174}$ Thus, again, common pitfalls in incremental and radical development seem to converge, whereas the appropriate managerial countermeasures diverge.

Concerning the external dimension of I/C alignment, common pitfalls reside in a failure to incorporate information and knowledge about technological development and product offers of competitors into internal development activities. These pitfalls apply to both incremental and radical development situations, but appear more severe in radical development. ${ }^{175}$ Proficient benchmarking of emergent product definitions helps mitigate these problems in incremental innovation, ${ }^{176}$ whereas environmental scanning by the development team applies to incremental and radical front-end development alike. In radical development, managers may address insufficient external I/C alignment by partnering with other firms or by building absorptive capacity, thus improving the abilities to recognize, assimilate, and apply external knowledge. ${ }^{177}$

Finally, in both incremental and radical development, any company needs to manage the legitimization system in which idea development is situated. A failure to do so may lead the firm to reject good ideas and concepts due to a lack of legitimization or, conversely, to push inadequate ideas and concepts too far for political reasons. ${ }^{178}$

Multiple managerial countermeasures are available to address these two problems, and they apply to incremental and radical front-end projects alike. First, senior management support may mitigate such problems because it can overcome resistance to change. Also, managers can mobilize organizational support and clarify development objectives. ${ }^{179}$ Second, cross-functional collaboration can cause emerging ideas and concepts to be better sanctioned throughout an organization. ${ }^{180}$ Finally, leadership provided by committed enthusiasts or product champions is another way to deal with legitimization problems. ${ }^{181}$

\section{Limitations}

Managers should be aware that our analysis applies mainly to the front end of incremental and radical development of assembled products. For non-assembled products, the front-end phase may deviate significantly concerning key activities. ${ }^{182}$ 
The front end for service development represents another idiosyncratic context. ${ }^{183}$ Our framework may therefore need adjustment regarding both product and industry effects, and managers must interpret the results carefully and draw their own conclusions by means of analogy.

\section{Notes}

1. R.G. Cooper, "Perspective: The Stage-Gate Idea to Launch Process-Update, What's New, and NexGen Systems," Journal of Product Innovation Management, 25/3 (May 2008): 213-232.

2. B. Kijkuit and J. van den Ende, "The Organizational Life of an Idea: Integrating Social Network, Creativity and Decision-Making Perspectives," Journal of Management Studies, 44/6 (September 2007): 863-882; A. Khurana and S.R. Rosenthal, “Towards Holistic 'Front Ends' in New Product Development," The Journal of Product Innovation Management, 15/1 (January 1998): 57.

3. R.G. Cooper, "Predevelopment Activities Determine New Product Success," Industrial Marketing Management, 17/3 (August 1988): 237-247; J. Björk and M. Magnusson, "Where Do Good Innovation Ideas Come From? Exploring the Influence of Network Connectivity on Innovation Idea Quality," The Journal of Product Innovation Management, 26/6 (November 2009): 662-670; R.G. Cooper and E.J. Kleinschmidt, "New Products-What Separates Winners from Losers," Journal of Product Innovation Management, 4/3 (September 1987): 169-184.

4. M.M. Montoya-Weiss and T.M. O'Driscoll, "From Experience: Applying Performance Support Technology in the Fuzzy Front End," Journal of Product Innovation Management, 17/2 (March 2000): 143-161.

5. S.L. Chang, C.Y. Chen, and S.C. Wey, "Conceptualizing, Assessing, and Managing Front-End Fuzziness in Innovation/NPD Projects," ReD Management, $37 / 5$ (November 2007): 469-478; J. Frishammar, H. Florén, and J. Wincent, "Beyond Managing Uncertainty: Insights from Studying Equivocality in the Fuzzy Front End of Product and Process Innovation Projects," IEEE Transactions on Engineering Management, 58/2 (August 2011): 551-563.

6. Khurana and Rosenthal (1998), op. cit.

7. R.W. Veryzer, "Discontinuous Innovation and the New Product Development Process," Journal of Product Innovation Management, $15 / 4$ (July 1998): 304-321.

8. U. Lichtenthaler and E. Lichtenthaler, "A Capability-Based Framework for Open Innovation: Complementing Absorptive Capacity," Journal of Management Studies, $46 / 8$ (December 2009): 1315-1338.

9. H. Chesbrough, "The Governance and Performance of Xerox's Technology Spin-Off Companies," Research Policy, 32/3 (March 2003): 403-421.

10. G. Bacon, S. Beckman, D. Mowery, E. Wilson, "Managing Product Definition in High-Technology Industries: A Pilot-Study," California Management Review, 36/3 (Spring 1994): 32-56.

11. J. Goldenberg, D.R. Lehmann, and D. Mazursky, “The Idea Itself and the Circumstances of Its Emergence as Predictors of New Product Success," Management Science, 47/1 (January 2001): 69-84.

12. Montoya-Weiss and O'Driscoll, op. cit.; J. Kim and D. Wilemon, "Strategic Issues in Managing Innovation's Fuzzy Front-End," European Journal of Innovation Management, 5/1 (2002a): 27-39; Khurana and Rosenthal (1998), op. cit.; A. Khurana and S.R. Rosenthal, "Integrating the Fuzzy Front End of New Product Development," Sloan Management Review, 38/2 (Winter 1997): 103-120; B. Verworn, “How German Measurement and Control Firms Integrate Market and Technological Knowledge into the Front End of New Product Development," International Journal of Technology Management, 34/3-4 (2006): 379-389.

13. Chang, Chen, and Wey, op. cit.; J. Kim and D. Wilemon, "Focusing the Fuzzy Front-End in New Product Development," ReD Management, 32/4 (September 2002b): 269-279; P. Koen et al., "Providing Clarity and a Common Language to the 'Fuzzy Front End'," Research-Technology Management, 44/2 (March/April 2001): 46-55; R.G. Cooper, S.J. Edgett, and E.J. Kleinschmidt, "Optimizing the Stage-Gate Process: What Best-Practice Companies Do-I," Research Technology Management, 45/5 (September/October 2002): 21-27.

14. Veryzer, op. cit.; M. Elmquist and B. Segrestin, "Towards a New Logic for Front End Management: From Drug Discovery to Drug Design in Pharmaceutical R\&D," Creativity and Innovation Management, 16/2 (June 2007): 106-120; U. de Brentani and S.E. Reid, "The Fuzzy Front-End of Discontinuous Innovation: Insight for Research and Management," Journal of Product Innovation Management, 29/1 (January 2012): 70-87. 
15. Lichtenthaler and Lichtenthaler, op. cit.; S. Anokhin, J. Wincent, and J. Frishammar, “A Conceptual Framework for Misfit Technology Commercialization," Technological Forecasting and Social Change, 78/6 (July 2011): 1060-1071.

16. R.S. Burt, "Structural Holes and Good Ideas," The American Journal of Sociology, 110/2 (2004): 349-399; J.E. Perry-Smith and C.E. Shalley, "The Social Side of Creativity: A Static and Dynamic Social Network Perspective," Academy of Management Review, 28/1 (January 2003): 89-106.

17. D.J. Teece, G. Pisano, and A. Shuen, "Dynamic Capabilities and Strategic Management," Strategic Management Journal, 18/7 (August 1997): 509-533; D.J. Teece, "Explicating Dynamic Capabilities: The Nature and Microfoundations of (Sustainable) Enterprise Performance," Strategic Management Journal, 28/13 (December 2007): 1319-1350.

18. J.G. March and H.A. Simon, Organizations (New York, NY: Wiley, 1958); R.R. Nelson and S.G. Winter, An Evolutionary Theory of Economic Change (Cambridge, MA: Belknap Press of Harvard University Press, 1982).

19. G.T. Lumpkin and B. Bergmann Lichtenstein, "The Role of Organizational Learning in the Opportunity-Recognition Process," Entrepreneurship Theory and Practice, 29/4 (July 2005): 451-472; G. Colarelli O'Connor and M.P. Rice, "Opportunity Recognition and Breakthrough Innovation in Large Firms," California Management Review, $43 / 2$ (Winter 2001): 95-116.

20. J. Griffiths-Hemans and R. Grover, "Setting the Stage for Creative New Products: Investigating the Idea Fruition Process," Journal of the Academy of Marketing Science, 34/1 (Winter 2006): 27-39.

21. Cooper (1988), op. cit.; Bacon et al., op. cit.; Khurana and Rosenthal (1998), op. cit.; GriffithsHemans and Grover, op. cit.

22. Goldenberg, Lehmann, and Mazursky, op. cit.; R.K. Moenaert et al., "R\&D/Marketing Communication During the Fuzzy Front-End," IEEE Transactions on Engineering Management, 42/3 (August 1995): 243-258; S.R. Rosenthal and M. Capper, "Ethnographies in the Front End: Designing for Enhanced Customer Experiences," Journal of Product Innovation Management, 23/3 (May 2006): 215-237; B. Verworn, "A Structural Equation Model of the Impact of the 'Fuzzy Front End' on the Success of New Product Development," Research Policy, 38/10 (December 2009): 1571-1581.

23. We use the notion of "idea and concept" throughout our discussion to capture the fact that ideas are gradually transformed into concepts, before materializing into product definitions.

24. Khurana and Rosenthal (1998), op. cit.; M.P. Rice et al., “Radical Innovation: Triggering Initiation of Opportunity Recognition and Evaluation," ReD Management, 31/4 (October 2001): 409-420.

25. Cooper, Edgett, and Kleinschmidt, op. cit.

26. Veryzer, op. cit.

27. Montoya-Weiss and O'Driscoll, op. cit.; Kim and Wilemon (2002a), op. cit.; Khurana and Rosenthal (1998), op. cit.; Khurana and Rosenthal (1997), op. cit.; Verworn, op. cit.

28. J.R. Dickinson and C.P. Wilby, "Concept Testing With and Without Product Trial," Journal of Product Innovation Management, 14/2 (March 1997): 117-125.

29. T.D. Parish and L.E. Moore, "Nonassembled Product Development," in M.D. Rosenau, ed., The PDMA Handbook of New Product Development (Hoboken, NJ: John Wiley and Sons, 1996).

30. Bacon et al., op cit.; Khurana and Rosenthal (1997), op. cit.

31. Kim and Wilemon (2002b), op. cit.

32. K.R. Popper, The Logic of Scientific Discovery (New York, NY: Basic Books, 1959); K.R. Popper, Objective Knowledge: An Evolutionary Approach (Oxford: Clarendon Press, 1972).

33. Colarelli $\mathrm{O}^{\prime}$ Connor and Rice, op. cit.

34. Elmquist and Segrestin, op. cit.

35. Kim and Wilemon (2002b), op. cit.

36. Rice et al., op. cit.

37. Griffiths-Hemans and Grover, op. cit.

38. Cooper, Edgett, and Kleinschmidt, op. cit.

39. P.G. Smith and D.G. Reinertsen, Developing Products in Half the Time (New York, NY: Van Nostrand Reinhold, 1991).

40. Griffiths-Hemans and Grover, op. cit.; H.-J. Boeddrich, "Ideas in the Workplace: A New Approach Towards Organizing the Fuzzy Front End of the Innovation Process," Creativity and Innovation Management, 13/4 (December 2004): 274.

41. Kim and Wilemon (2002b), op. cit.

42. Kim and Wilemon (2002b), op. cit.

43. Lumpkin and Bergmann Lichtenstein, op. cit.; G.S. Lynn, J.G. Morone, and A.S. Paulson, "Marketing and Discontinuous Innovation: The Probe and Learn Process," California Management Review, 38/3 (Spring 1996): 8-37. 
44. Seidel, op. cit.

45. G.R. Smith, W.C. Herbein, and R.C. Morris, "Front-End Innovation at Alliedsignal and Alcoa," Research-Technology Management, $42 / 6$ (1999): 15-24.

46. Cooper (1988), op. cit.

47. O. Ihlen, "Defending the Mercedes A-Class: Combining and Changing Crisis-Response Strategies," Journal of Public Relations Research, 14/3 (July 2002): 185-206.

48. S.D. Eppinger, "Innovation at the Speed of Information," Harvard Business Review, 79/1 (January 2001): 149-158.

49. A. Griffin and J.R. Hauser, "Integrating R\&D and Marketing: A Review and Analysis of the Literature," Journal of Product Innovation Management, 13/3 (May 1996): 191-215.

50. J. Singh and L. Fleming, "Lone Inventors as Sources of Breakthroughs: Myth or Reality?" Management Science, 56/1 (January 2010): 41-56.

51. Verworn, op. cit.; Moenaert et al., op. cit.; G. Gemser and M.A.A.M. Leenders, "Managing Cross-Functional Cooperation for New Product Development Success," Long Range Planning, 44/1 (February 2011): 26-41; H.-H. Schroder and A.J.M. Jetter, "Integrating Market and Technological Knowledge in the Fuzzy Front End: An FCM-Based Action Support System," International Journal of Technology Management, 26/5-6 (2003): 517.

52. Bacon et al., op. cit.; R. Verganti, "Leveraging on Systemic Learning to Manage the Early Phases of Product Innovation Projects," ReD Management, 27/4 (October 1997): 377.

53. P. Groenveld, "Roadmapping Integrates Business and Technology," Research Technology Management, 40/5 (September/October 1997): 48.

54. K. Girotra, C. Terwiesch, and K.T. Ulrich, "Idea Generation and the Quality of the Best Idea," Management Science, 56/4 (April 2010): 591-605.

55. L. Fleming and M. Marx, "Managing Creativity in Small Worlds," California Management Review, 48/4 (Summer 2006): 6-27.

56. Verworn, op. cit.; Kim and Wilemon (2002b), op. cit.; Smith, Herbein, and Morris, op. cit.; B. Verworn, C. Herstatt, and A. Nagahira, "The Fuzzy Front End of Japanese New Product Development Projects: Impact on Success and Differences between Incremental and Radical Projects," RथD Management, 38/1 (January 2008): 1-19.

57. Cooper (1988), op. cit.; Cooper and Kleinschmidt, op. cit.; Verworn, Herstatt, and Nagahira, op. cit.; K.A. Zien and S.A. Buckler, "Dreams to Market: Crafting a Culture of Innovation," Journal of Product Innovation Management, 14/4 (July 1997): 274-287; E. von Hippel, "Lead Users: A Source of Novel Product Concepts," Management Science, 32/7 (July 1986): 791-805.

58. Kim and Wilemon (2002a), op. cit.; Cooper, Edgett, and Kleinschmidt, op. cit.

59. R. Cooper and E.J. Kleinschmidt, "An Investigation into the New Product Process: Steps, Deficiencies, and Impact," Journal of Product Innovation Management, $3 / 2$ (June 1986): 71-95; R. Rothwell, "Towards the Fifth-Generation Innovation Process," International Marketing Review, 11/1 (1994): 7-31.

60. M. Williams, "Sony Scores Smash Hit with New Vaio W," IDG News Service, March 20, 2002; E. Veldhuizen, E.J. Hultink, and A. Griffin, "Modeling Market Information Processing in New Product Development: An Empirical Analysis," Journal of Engineering and Technology Management, $23 / 4$ (December 2006): 353-373.

61. See <www.itt.com/IOHextra/rell3/articlel.html>.

62. P.A. Murmann, "Expected Development Time Reductions in the German MechanicalEngineering Industry," Journal of Product Innovation Management, 11/3 (June 1994): 236-252.

63. Kim and Wilemon (2002b), op. cit.

64. Kim and Wilemon (2002b), op. cit.

65. U. Lichtenthaler and E. Lichtenthaler, “Technology Transfer across Organizational Boundaries: Absorptive Capacity and Desorptive Capacity," California Management Review, 53/1 (Fall 2010): 154-170.

66. S. Bröring, L.M. Cloutier, and J. Leker, "The Front End of Innovation in an Era of Industry Convergence: Evidence from Nutraceuticals and Functional Foods," ReD Management, 36/5 (November 2006): 487-498.

67. Y. Doz and M. Kosonen, "Letter to the Editor: Nokia and Strategic Agility: A Postscript," California Management Review, 53/4 (Summer 2011): 154-156.

68. A.S.O. Yu, P.S. Figueiredo, and P. Tromboni se Souza Nascimento, "Development Resource Planning: Complexity of Product Development and the Capacity to Launch New Products," Journal of Product Innovation Management, $27 / 2$ (March 2010): 253-266.

69. R.A. Burgelman, C.M. Christensen, and S.C. Wheelwright, Strategic Management of Technology and Innovation, 4th edition (Boston, MA: McGraw-Hill Irwin, 2004).

70. Cooper (1988), op. cit. 
71. H. Chesbrough, "Managing Open Innovation," Research-Technology Management, 47/1 (January/ February 2004): 23-26.

72. S. Hart et al., "Industrial Companies' Evaluation Criteria in New Product Development," Journal of Product Innovation Management, $20 / 1$ (January 2003): 22-36.

73. Hart et al., op. cit.; A. Griffin and A.L. Page, "PDMA Success Measurement Project: Recommended Measures for Product Development Success and Failure," Journal of Product Innovation Management, 13/6 (November 1996): 478-496; I.C. Kerssens-van Drongelen and A. Cock, “Design Principles for the Development of Measurement Systems for Research and Development Processes," ReD Management, 27/4 (1997): 345-357; H. Ernst, "Success Factors of New Product Development: A Review of the Empirical Literature," International Journal of Management Reviews, 4/1 (March 2002): 1-40.

74. M.J. Liberatore and A.C. Stylianou, "Expert Support Systems for New Product Development Decision Making: A Modeling Framework and Applications," Management Science, 41/8 (August 1995): 1296-1316.

75. Girotra, Terwiesch, and Ulrich, op. cit.

76. J. Grönlund, D. Rönnberg-Sjödin, and J. Frishammar, “Open Innovation and the Stage-Gate Process: A Revised Model for New Product Development," California Management Review, 52/3 (Spring 2010): 106-131.

77. Girotra, Terwiesch, and Ulrich, op. cit.

78. W. Hammedi, A.C.R. van Riel, and Z. Sasovova, "Antecedents and Consequences of Reflexivity in New Product Screening," Journal of Product Innovation Management, 28/5 (September 2011): 662-679; H.M.J. Bertels, E.J. Kleinschmidt, and P.A. Koen, “Communities of Practice Versus Organizational Climate: Which One Matters More to Dispersed Collaboration in the Front End of Innovation," Journal of Product Innovation Management, 28/5 (September 2011): 757-772.

79. A. Hagardon and R.I. Sutton, "Technology Brokering and Innovation in a Product Development Firm," Administrative Science Quarterly, 42/4 (December 1997): 718-749; J. Howells, "Intermediation and the Role of Intermediaries in Innovation," Research Policy, 35/5 (June 2006): 715-728.

80. C.T. Lin and C.T. Chen, "New Product Go/No-Go Evaluation at the Front End: A Fuzzy Linguistic Approach," IEEE Transactions on Engineering Management, 51/2 (May 2004): 197-207.

81. Grönlund, Rönnberg-Sjödin, and Frishammar, op. cit.

82. Burgelman, Christensen, and Wheelwright, op. cit.

83. S.A. Murphy and V. Kumar, "The Front End of New Product Development: A Canadian Survey," ReD Management, 27/1 (January 1997): 5-15.

84. Ibid.

85. Cooper and Kleinschmidt (1987), op. cit.; Verworn, Herstatt, and Nagahira, op. cit.; Murmann, op. cit.

86. Cooper (1988), op. cit.

87. Anokhin, Wincent, and Frishammar, op. cit.

88. Murphy and Kumar, op. cit.; X.M. Song and M.E. Parry, "What Separates Japanese New Product Winners from Losers," Journal of Product Innovation Management, $13 / 5$ (September 1996): 422-439.

89. Khurana and Rosenthal (1988), op. cit.; Khurana and Rosenthal (1997), op. cit.

90. Bacon et al., op. cit.

91. Verganti, op. cit.; Murphy and Kumar, op. cit.

92. Khurana and Rosenthal (1997), op. cit.

93. Kim and Wilemon (2002a), op. cit.

94. M.H. Meyer and M.H. Zack, "The Design and Development of Information Products," Sloan Management Review, 37/3 (Spring 1996): 43-59.

95. C.H. Killen, R.A. Hunt, and E.J. Kleinschmidt, "Managing the New Product Development Project Portfolio: A Review of the Evidence," in Portland International Conference on Managing Engineering and Technology (PICMET), Portland, OR, 2007; E.F. McDonough III and F.C. Spital, "Managing Product Portfolios," Research Technology Management, 46/3 (May 2003): 40-46; C.M. Christensen and M.E. Raynor, The Innovator's Solution: Creating and Sustaining Successful Growth (Boston, MA: Harvard Business School Press, 2003).

96. C.H. Killen, R.A. Hunt, and E.J. Kleinschmidt, "Project Portfolio Management for Product Innovation Management," International Journal of Quality and Reliability Management, 25/1 (2008): 24-38.

97. Lichtenthaler and Lichtenthaler, op. cit.

98. A. Fosfuri, "The Licensing Dilemma: Understanding the Determinants of the Rate of Technology Licensing," Strategic Management Journal, 27/12 (December 2006): 1141-1158. 
99. J.S. Gans and S. Stern, “The Product Market and the Market for 'Ideas': Commercialization Strategies for Technology Entrepreneurs," Research Policy, 32/2 (February 2003): 333-350.

100. K.G. Rivette and D. Kline, Rembrandts in the Attic: Unlocking the Hidden Value of Patents (Boston, MA: Harvard Business School Press, 2000).

101. Bacon et al., op. cit.

102. W.M. Cohen and D.A. Levinthal, "Absorptive Capacity: A New Perspective on Learning and Innovation," Administrative Science Quarterly, 35/1 (March 1990): 128-152; S.A. Zahra and G. George, "Absorptive Capacity: A Review, Reconceptualization, and Extension," Academy of Management Review, 27/2 (April 2002): 128-152.

103. J.H. Dyer, P. Kale, and H. Singh, "When to Ally and When to Acquire," Harvard Business Review, 82/7-8 (July/August 2004): 108-115.

104. Bröring, Cloutier, and Leker, op. cit.

105. H. Chesbrough and R.S. Rosenblom, "The Role of the Business Model in Capturing Value from Innovation: Evidence from Xerox Corporation's Technology," Industrial and Corporate Change, 11/3 (June 2002): 529-555.

106. J. Bower, Managing the Resource Allocation Process (Boston, MA: Harvard University Press, 1970); C.M. Christensen and J.L. Bower, "Customer Power, Strategic Investment, and the Failure of Leading Firms," Strategic Management Journal, 17/3 (March 1996): 197-218.

107. "Winning through Incremental Innovation," Chief Executive, (January/February 2003), pp. 10-12.

108. Anokhin, Wincent, and Frishammar, op. cit.; Grönlund, Rönnberg-Sjödin, and Frishammar, op. cit.

109. Kijkuit and van den Ende, op. cit.; M.A. Weissenberger-Eibl and B. Teufel, "Organizational Politics in New Product Development Project Selection," European Journal of Innovation Management, 14/1 (2011): 51 .

110. A.H. Van de Ven, "Central Problems in the Management of Innovation," Management Science, 32/5 (May 1986): 590; L. Prasad and A.H. Rubenstein, “Conceptualizing Organizational Politics as a Multidimensional Phenomenon: Empirical-Evidence from a Study of Technological Innovations," IEEE Transactions on Engineering Management, 39/1 (February 1992): 4-12.

111. Griffiths-Hemans and Grover, op. cit.

112. Cooper (2008), op. cit.

113. M.K. Badawy, "Managing Human Resources," Research-Technology Management, 50/4 (July/ August 2007): 56-74.

114. R. Moss Kanter, "The Middle Manager as Innovator," Harvard Business Review, 82/7-8 (July/ August 2004): 150.

115. Chesbrough (2003), op. cit.; Kim and Wilemon (2002b), op. cit.; Griffiths-Hemans and Grover, op. cit.

116. S.K. Markham, "Corporate Championing and Antagonism as Forms of Political Behavior: An R\&D Perspective," Organization Science, 11/4 (July/August 2000): 429-447.

117. Cooper (2008), op. cit.

118. R. McAdam and D. Leonard, "Reengineering Based Inquiry into Innovation in the Front End of New Product and Service Development Processes," International Journal of Product Development, 1/1 (2004): 66-91.

119. Murphy and Kumar, op. cit.

120. Koen et al., op. cit.

121. Kim and Wilemon (2002a), op. cit.; Kim and Wilemon (2002b), op. cit.

122. H.A. Conway and N.W. Mcguinness, "Idea Generation in Technology-Based Firms," Journal of Product Innovation Management, $3 / 4$ (December 1986): 276-291.

123. R.M. Grant, Contemporary Strategy Analysis, 5th edition (Malden, MA: Blackwell, 2005).

124. Kim and Wilemon (2002a), op. cit.; Conway and Mcguinness, op. cit.

125. Kim and Wilemon (2002a), op. cit.; Kim and Wilemon (2002b), op. cit.

126. X.A. Koufteros, M.A. Vonderembse, and W.J. Doll, "Integrated Product Development Practices and Competitive Capabilities: The Effects of Uncertainty, Equivocality, and Platform Strategy," Journal of Operations Management, 20/4 (August 2002): 331-355; R. Rauniar et al., "The Role of Heavyweight Product Manager in New Product Development," International Journal of Operations $\theta$ Production Management, 28/2 (2008): 130-154.

127. Khurana and Rosenthal (1997), op. cit.

128. Markham, op. cit.

129. Van de Ven, op. cit.

130. Seidel, op. cit.; E. Danneels and E.J. Kleinschmidt, "Product Innovativeness from the Firm's Perspective: Its Dimensions and Their Relation with Project Selection and Performance," Journal of Product Innovation Management, 18/6 (November 2001): 357-373. 
131. Seidel, op. cit.

132. Verworn, Herstatt, and Nagahira, op. cit.

133. Veryzer (1998), op. cit.

134. Veryzer (1998), op. cit.

135. G.C. O'Connor and R.W. Veryzer, "The Nature of Market Visioning for Technology-Based Radical Innovation," Journal of Product Innovation Management, 18/4 (July 2001): 231-246.

136. Elmquist and B. Segrestin, op. cit.

137. T. Heller, “'If Only We'd Known Sooner': Developing Knowledge of Organizational Changes Earlier in the Product Development Process," IEEE Transactions on Engineering Management, 47/3 (August 2000): 335; R. McAdam and D. Leonard, "Reengineering Based Inquiry into Innovation in the Front End of New Product and Service Development Processes," International Journal of Product Development, 1/1 (2004): 66-91.

138. Khurana and Rosenthal (1998), op. cit.

139. De Brentani and Reid, op. cit.; S.E. Reid and U. de Brentani, "The Fuzzy Front End of New Product Development for Discontinuous Innovations: A Theoretical Model," Journal of Product Innovation Management, 21/3 (May 2004): 170-184.

140. Seidel, op. cit.: Veryzer (1998), op. cit.

141. Lynn, Morone, and Paulson, op. cit.

142. Veryzer (1998), op. cit.

143. Von Hippel, op. cit.

144. Lynn, Morone, and Paulson, op. cit.; Elmquist and Segrestin, op. cit.

145. R.W. Veryzer, "The Roles of Marketing and Industrial Design in Discontinuous New Product Development," Journal of Product Innovation Management, 22/1 (January 2005): 22-41.

146. M. Martinsuo and J. Poskela, "Use of Evaluation Criteria and Innovation Performance in the Front End of Innovation," Journal of Product Innovation Management, 28/6 (November 201 1): 896-914.

147. C. Gilbert and J.L. Bower, "Disruptive Change: When Trying Harder Is Part of the Problem," Harvard Business Review, 80/5 (May 2002): 95-100.

148. P. Anderson and M.L. Tushman, "Technological Discontinuities and Organizational Environments," Administrative Science Quarterly, 31/3 (September 1986): 439-465.

149. Veryzer (1998), op. cit.; M.X. Song and M.M. Montoya-Weiss, "Critical Development Activities for Really New Versus Incremental Products," Journal of Product Innovation Management, 15/2 (March 1998): 124-135.

150. Bröring, Cloutier, and Leker, op. cit.

151. Veryzer (1998), op. cit.

152. Koen et al., op. cit.

153. Veryzer (1998), op. cit.; Khurana and Rosenthal (1998), op. cit.

154. Veryzer (1998), op. cit.

155. Kim and Wilemon (2002a), op. cit; Smith, Herbein, and Morris, op. cit.

156. Kim and Wilemon (2002a), op. cit.; Murmann, op. cit.

157. Veryzer (1998), op. cit.; E. von Hippel, The Sources of Innovation (Cambridge: MIT Press, 1988).

158. Reid and de Brentani, op. cit.

159. R.W. Veryzer, "The Place of Product Design and Aesthetics in Consumer Research," in L. McAlister and M.L. Rothschild, eds., Advances in Consumer Research (Provo, UT: Association for Consumer Research, 1995). p. 224-228.

160. Griffin and Hauser, op. cit.

161. Lichtenthaler and Lichtenthaler, op. cit.

162. Veryzer (1998), op. cit.

163. Seidel, op. cit.

164. Griffiths-Hemans and Grover, op cit.; Murphy and Kumar, op. cit.

165. Grönlund, Rönnberg-Sjödin, and Frishammar, op. cit.

166. Murphy and Kumar, op. cit.

167. Verworn, Herstatt, and Nagahira, op. cit.; Murmann, op. cit.

168. Elmquist and Segrestin, op. cit.

169. Howells, op. cit.

170. Khurana and Rosenthal (1988), op. cit.; Khurana and Rosenthal (1997), op. cit.; Song and Parry, op. cit.

171. Cooper (2008), op. cit.; Anderson and Tushman, op. cit.

172. Song and Montoya-Weiss, op. cit.

173. Grönlund, Rönnberg-Sjödin, and Frishammar, op. cit. 
174. Lichtenthaler and Lichtenthaler, op. cit.; E. Lichtenthaler and J. Frishammar, "The Impact of Aligning Product Development and Technology Licensing: A Contingency Perspective," Journal of Product Innovation Management, 28/1 (November 2011): 89-103.

175. Verworn, Herstatt, and Nagahira, op. cit.

176. Bacon et al., op. cit.

177. Bröring, Cloutier, and Leker, op. cit.; Cohen and Levinthal, op. cit.; Zahra and George, op. cit.

178. Cooper (2008), op. cit.; Kim and Wilemon (2002b), op. cit.; Griffiths-Hemans and Grover, op. cit.; Markham, op. cit.

179. Kim and Wilemon (2002a), op. cit.; Kim and Wilemon (2002b), op. cit.; McAdam and Leonard, op. cit.

180. Conway and Mcguinness, op. cit.

181. Veryzer (1998), op. cit.; Khurana and Rosenthal (1997), op. cit.; Koufteros, Vonderembse, and Doll, op. cit.

182. M. Kurkkio, J. Frishammar, and U. Lichtenthaler, "Where Process Development Begins: A Multiple Case Study of Front End Activities," Technovation, $31 / 9$ (September 2011): 490-504.

183. R. Barras, "Towards a Theory of Innovation in Services," Research Policy, 15/4 (August 1986): 161-173.

California Management Review, Vol. 54, No. 4, pp. 20-43. ISSN 0008-1256, eISSN 2162-8564. ( 2012 by The Regents of the University of California. All rights reserved. Request permission to photocopy or reproduce article content at the University of California Press's Rights and Permissions website at http://www.ucpressjournals.com/reprintinfo.asp. DOI: 10.1525/cmr.2012.54.4.20. 